\title{
Trip Attraction Development Statistical Model in Dohuk City Residential Area
}

\author{
Dr.Abdul Khalik Al-Taei \\ Assistant Prof. \\ Transportation Engineering \\ Civil Engineering Dept. /College of \\ Eng. \\ University of Dohuk
}

Amal M. Taher

Assistant Lecturer.

Transportation Engineering

Civil Engineering Dept. /College of Eng.

University of Dohuk

\section{ABSTRACT}

In this study, trip attraction phenomenon has been studied for 20 residential out of 28 traffic zones located within Dohuk city urban area composed of more than 300,000 in residents. Home-interview travel data provided for the city are used in addition to special data collected to perform the trip attraction analysis .Attraction trips are classified into seven types and selected as dependent variables while other variables like number of dwelling units, employment,....etc., are selected as independent variables in the SPSS package to obtain the most statistically well accepted predicted attraction trip models. Some models like HBW trips is constant eliminated with good $\left(\mathrm{R}^{2}\right)$ value. HBSH and $\mathrm{HBOH}$ trips are showing weak correlation with their independent variables like amount of $\mathrm{CBD}$ area and number of retail sales located within CBD area.

\section{Key Word: Trip Attraction}

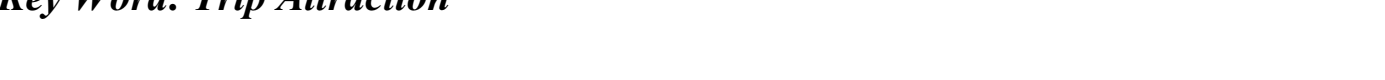 \\ Bga' rgt'fź}

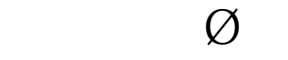

¿

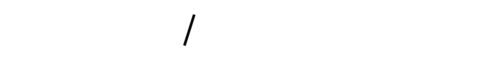

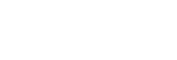

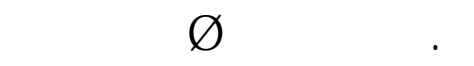

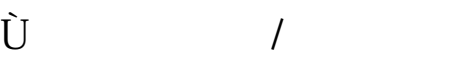

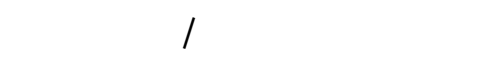

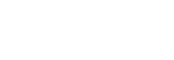

\section{rU゚t ŤKE}

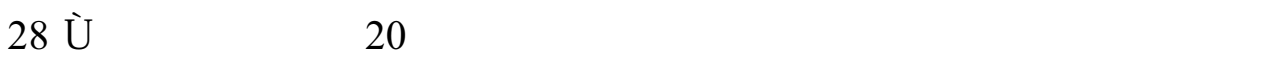

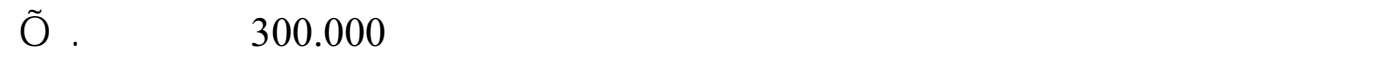

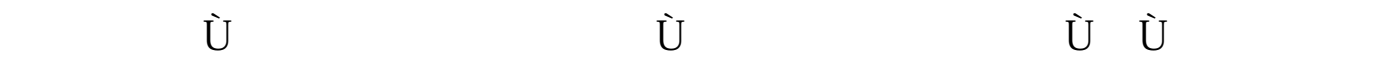

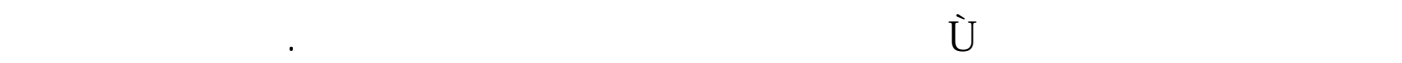

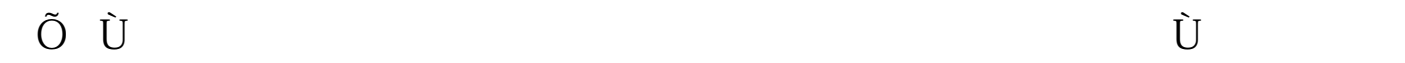

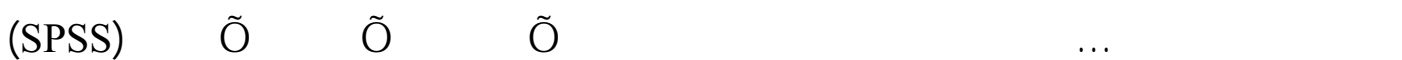

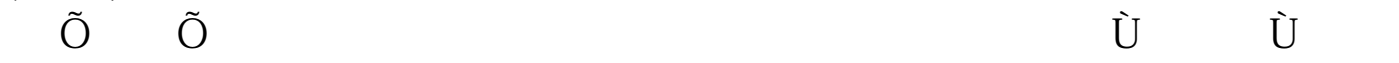

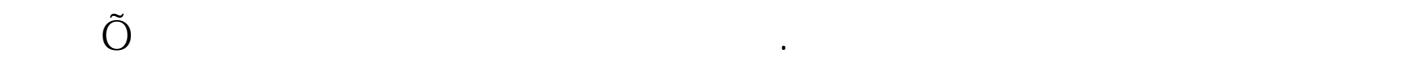

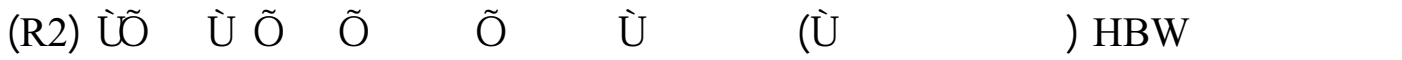

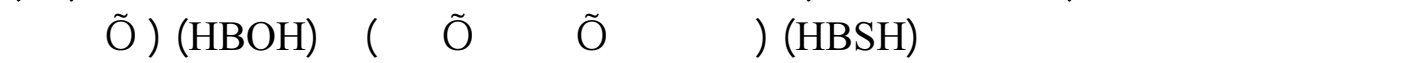

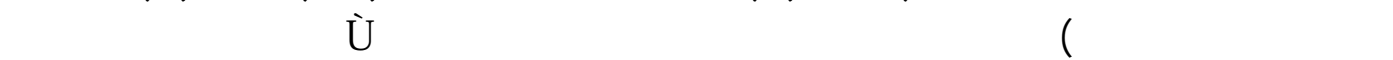

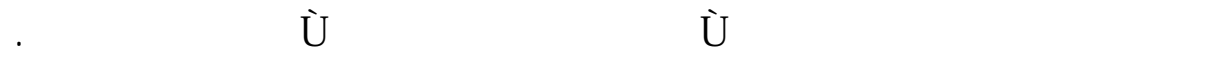

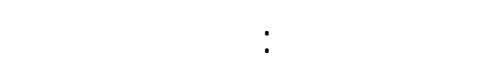




\section{Introduction}

Transportation problems present a number of the constituent complex factors of urban problems. In fact in many respects, transportation may be considered as one of the major causes of present urban problems .In this process., Planners develop information about the impacts of implementing alternative courses of action involving transportation services such as, new highways, bus route change, and parking restrictions.

Trip generation provides the linkage between land use, and travel. It is separated into two phases:

Phase1:Understanding and quantification of the amount of travel, and land use linkage is developed, and

Phase2:Quantification results are applied to forecast land use characteristics and to develop future travel estimates.

For trip generation purposes, travel is considered in terms of trip ends and/or number of trips. It does not consider the other characteristics such as direction, length, or duration of trips. Trips considered are usually those generated for an average weekday ,but they may also be for weekend travel, particularly trip purpose, mode of travel, and/or other stratification required for a specific analysis or forecasting purposes $(1,2)$.

Trips ends may be in terms of origins and destinations, or in terms of productions, and attractions depending upon the purpose to be forecasted and the subsequent models to be used for trip distribution and modal choice (2).Land use for trip generation purposes is usually described in terms of land use intensity, character of the land use activities and location within the urban environment. These measures are the main inputs to trip generation., trip rate, regression, and cross-classification analysis are the main techniques linked with land use to measure trip generations. These techniques are then utilized and applied to forecast/and use and to develop future travel $(2,3)$.

Urban transportation process is already based on a comprehensive study of an urbanized area, and includes the following phases:

Phase 1:Formulation of goals, and objectives;

Phase 2:Process organization and data assembly;

Phase 3:Model calibration and

Phase 4:Area wide study.

\section{Trip Generation Models}

Trip generation refers to both trip production(i.e, typically emanating from the home or the beginning point of a non-home based trip), and trip attraction(i.e; to the point where an out of home activity will be undertaken), on zonal and regional level through the origin-destination(O-D),survey models to predict both types of trips can be correlated to social, and economic characteristics of each house-hold for existing condition(i.e; base year), and future(i.e; horizon year). 
Trip generation analysis phase is interesting to develop equations that allow the trip ends of a particular or trip type generated by traffic analysis zones. This analysis is used most commonly used for the development of these prediction equations by multiple regression and cross-classification analysis. For trip attraction models the multiple regression technique was preferred based on the variables used (3).

\section{Scope of the Study}

This study was mainly implemented to provide the followings:

1-Compilation and analysis of the (O-D) survey data collected by a previous study in addition to a new set of data survey especially related to trip attraction analysis in Dohuk city ( 5,6 ).

2-Developing (O-D),survey data for the non-residential zones within Dohuk city; and

3-Developing a suitable trip attraction modeling system to forecast future travel in the city using some computer software packages for the city.

\section{Study Area and Site Location}

The study area was divided into 27 analysis units defined as traffic analysis zones(TAZ). These 27 zones were designed to be relatively homogenous in land use that 20 zones out of them are mainly residential and constitute the main trip generation demand of the city. The other remaining zones represented for medical, commercial, educational, and constitutional purpose.

Residential zones were selected only but other special considerations were given to analysis areas or zones containing unique characteristics such as (CBD), office buildings, and the land which contains stadium, or retail sales areas.

Figure ( 1 ),contains the main analysis units considered in this study from which different data about trip attractions were collected.

\section{Data Source}

Data were taken from other previously implemented (O-D), survey in the urban transportation study conducted for the city of Dohuk in 2001(5).Home interview survey collected data for 2437 families was conducted to characterize demographics of household members and travel pattern of household members for life style trips using special form.. For trip attraction other additional information was needed for the same study area like zonal area amount, school enrollment, distance from $\mathrm{CBD}$ to each zone center, retail sales, mainly from maps found in the Municipality Directorate of Dohuk city(7).

Data summary about the zonal additional characteristics are shown in table (1). Trip attraction purposes were considered also in 5 types in this study reflecting the amount of total attraction conducted in a typical day within the study area. All trips are classified either Home Based Trips (HBT),or trips did not end at home called Non-Home Based Trips (NHBT).The 5 types classified in this study are as follows: 
1-Home-Based Work (HBW), those trips conducted between personal place of residence and his place of employment;

2-Home-Based Education(HBED), those trips by students performed between place of residence, and school for the purpose of attending classes;

3-Home-Based Shopping(HBSH), these trips between personal place of residence and a commercial establishment for the purpose of shopping;

4-Home-Based Social(HBSO), those trips between personal place of residence, and place of cultural social ; and

5-Home Based Other(HBO); all trips oriented to personal place of residence for miscellaneous trip purpose other than those listed above. Table ( 2 ), shows the different types of data according to purpose described before.

\section{Variable Definitions}

The dependent variables selected for analysis is regarded as daily personal attracted trips with respect to purpose:

$\begin{array}{lc}\text { 1-HBW trips } & \text { Y1 } \\ \text { 2-HBSO trips } & \text { Y2 } \\ \text { 3-HBSH trips } & \text { Y3 } \\ \text { 4-HBED trips } & \text { Y4 } \\ \text { 5-HBO trips } & \text { Y5 } \\ \text { 6-NHB trips } & \text { Y6 } \\ \text { 7-Total attracted personal trips } & \text { Y7 }\end{array}$

The independent variables collected from the two survey data sources are prepared and described as given below;

$\begin{array}{ll}\text { 1-Number of dwelling units(DU) } & \text { X1 } \\ \text { 2-Number of employment } & \text { X2 } \\ \text { 3-Number of workers } & \text { X3 } \\ \text { 4-Total area } & \text { X4 } \\ \text { 5-Retail sales } & \text { X5 } \\ \text { 6-School enrollment } & \text { X6 } \\ \text { 7-Distance to CBD } & \text { X7 } \\ \text { 8-Number of schools } & \text { X8 }\end{array}$

\section{Stepwise Regression Analysis}

Statistical package for social sciences (SPSS), is extremely powerful tool used in this analyses. Stepwise method is by far the most versatile and helpful in the analysis. In this method one variable is added at each step and statistical tests were conducted to determine the improvement in the equation and variables are continuously to be added until the maximum step specified is reached to obtain the most meaningful interpolation results of tests examined at each step. This will include the increase in the multiple correlation coefficient( $\mathrm{R})$, or the multiple determination coefficient $\left(\mathrm{R}^{2}\right)$. The increase or decrease in the standard error of estimate(STD), and the t-test value on each regression equation.. F-test can be obtained automatically for variance test in order to reject or accept the null hypotheses. 


\section{Prediction Trip Attraction}

Using the multiple linear regression analysis technique between all independent and dependent variables table ( 3 ), listed all the equations chosen from the analysis with $\left(\mathrm{R}^{2}\right.$ ), and ( STD )values.

HBW trips attracted are positively affected by the employment number but decrease with the dwelling units as work trips attracted to certain zone from institutional offices or shopping but not from residential units.

HBSH trips take no variable zonal area is the most effective on HBSO trips and when this area becomes large no increase in dwelling units will happen and this type of trips is going to expand.

NHB trips seem to be affected positively by employment number and school enrollment as they constitute the largest group of trip makers in the society for five days of the week.. The three equations predicted show $\left(\mathrm{R}^{2}\right)$,values more than 0.533 which is extremely reliable (4).

HBSH,HBOTH and HBED trips did not accept any variable ,for this reason another method of analysis was used by the elimination of constant or using nonlinear analysis.

\section{Elimination of the Regression Constant}

Problems occur in forecasting where regression turns out to be either quite large or negative or both and/or when there is no equation like NHB,HBSH,HBOTH and HBTH trips constant elimination can be implemented as shown in table ( 4 ).Initial selection is usually an attempt to modify the equation into suitable form. This method is preferable for better evaluation of the basic data and their relationships with other factors to obtain more realistic results from the estimated equation. $\left(\mathrm{R}^{2}\right)$,values obtained are preferably accepted except $\mathrm{HBSH}$ and HBOTH attracted trips.

\section{Non-Linear Regression Analysis}

Final step in the regression analysis is conducted by dividing the equation required into subsets based on those variables selected from stepwise regression results. This was performed by the addition of non-linear regression models with largest $\left(\mathrm{R}^{2}\right)$,measure. From the examination of the individual analysis, certain relationships of the independent one might appear. Table(5),shows the obtained results. $\left(\mathrm{R}^{2}\right)$,values are not reliable with the transform-action equation.

\section{Conclusion and Recommendations}

The models shown in Table (6) can be considered as trip attraction prediction equations to forecast future trip generation in the Dohuk city especially if employment numbers ,school enrollments, number of schools and retail sales are going to change. It can be concluded ,that HBW could be better predicted by constant eliminated shape model with $\operatorname{good}\left(\mathrm{R}^{2}\right)$,value but HBOTH with weak $\left(\mathrm{R}^{2}\right)$ value. Retail sales and CBD area values are sufficient to predict HBSH but with small $\left(\mathrm{R}^{2}\right)$,value. 
Out of the results and data interviewed from this study it can be recommended that further results can be obtained if local study of trip attraction is performed on each trip attraction major center like super markets, commercial, educational, and recreational areas within the city of Dohuk to more effectively reflect its attraction size on the city transport volume.

\section{References}

1-C.S.,Papacostas "Fundamentals of Transportation Engineering" Prectice Hall,2003.

2-FHWA,"Trip Generation Analysis" U.S, Department of Transportation" ,U.S., Department of Transportation, Washington, D.C., December 1975.

3-AASHTO, and, FHWA. ,'Quick-Response Urban Travel Estimation Techniques and Transferable Parameters "Users, Guide, National Research Council, Washington ,D.C., 1978.

4-Mc- Carthy .G.M., "Multiple-Regression Analysis of Household Trip Generation-A Critique" Transportation Research Board 250,pp(31-43).

5-Amal M.T., "Trip Production Analysis of Urban Area in Dohuk City” ,M.Sc, Thesis, College of Engineering, Dohuk University,October,2002.

6-Kassof, H, and ,Deuchman H,D, "Trip Generation. A Critical Appraisal" ,Transportation Research Board 250 pp( 18-25).

7-Dohuk City Municipality Directorate" Dohuk City General Land Use Maps". 


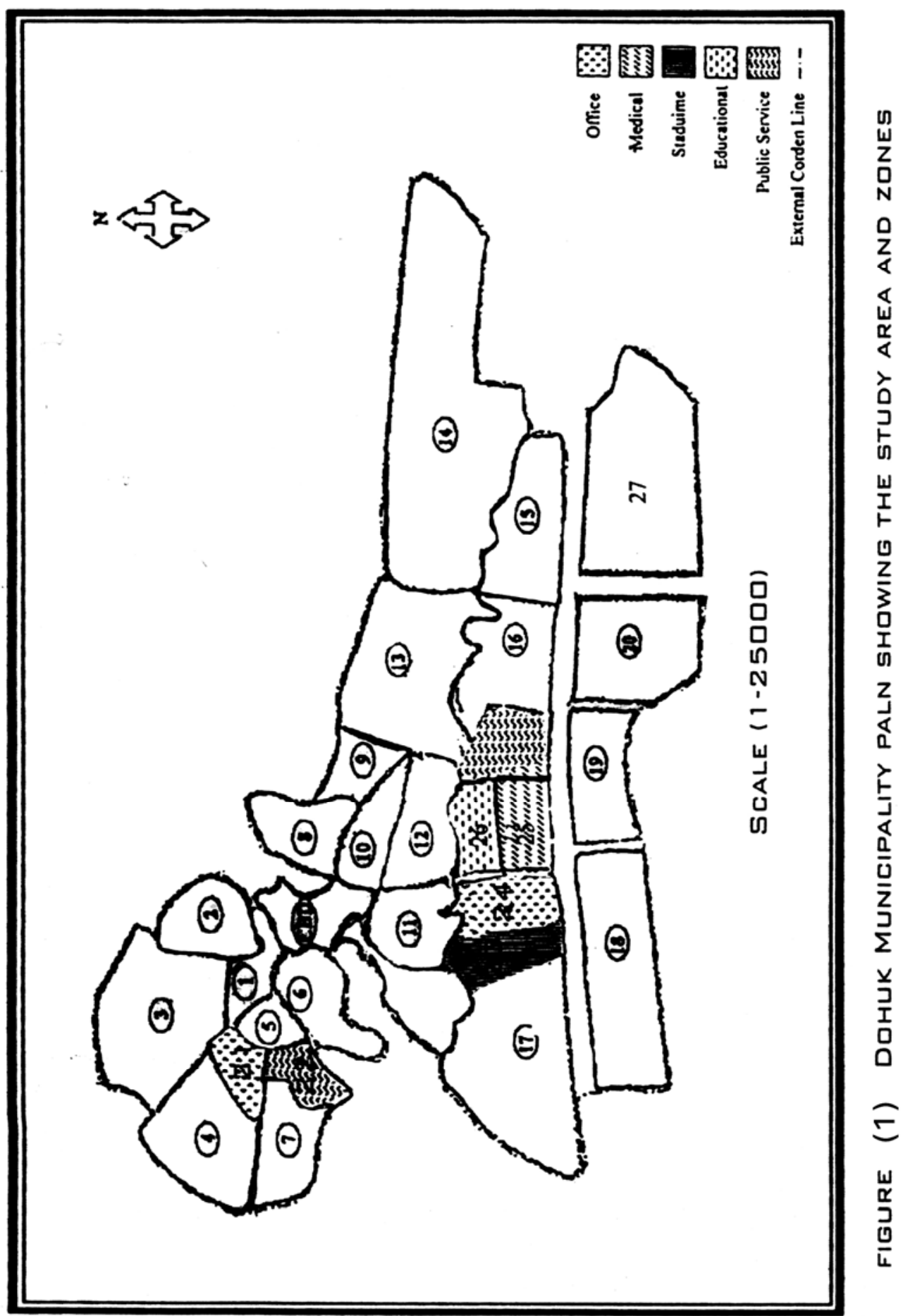


Table (1)

Zonal Characteristics Related to Trip Attraction Collected

\begin{tabular}{|c|c|c|c|c|c|c|c|c|}
\hline$\#$ & $\begin{array}{c}\text { No. } \\
\text { DU }\end{array}$ & $\begin{array}{c}\text { Total Area } \\
\text { km2 }\end{array}$ & Employ & Worker & $\begin{array}{c}\text { Retail } \\
\text { sales }\end{array}$ & $\begin{array}{c}\text { School } \\
\text { enrollment }\end{array}$ & $\begin{array}{c}\text { Distance to } \\
\text { CBD }\end{array}$ & $\begin{array}{c}\text { No. of } \\
\text { schools }\end{array}$ \\
\hline 1 & 995 & .155 & 1031 & 1021 & 1221 & 2020 & .4635 & 5.0000 \\
\hline 2 & 640 & .415 & 700 & 908 & 1680 & 1354 & .4697 & 3.0000 \\
\hline 3 & 1273 & 1.081 & 1728 & 1410 & 1081 & 1437 & .9159 & 9.0000 \\
\hline 4 & 1570 & .738 & 2179 & 961 & 1560 & 2123 & 1.3615 & 5.0000 \\
\hline 5 & 262 & .172 & 108 & 355 & 888 & 1431 & .6414 & 3.0000 \\
\hline 6 & 408 & .412 & 452 & 321 & 1128 & 1079 & .4202 & 4.0000 \\
\hline 7 & 520 & .424 & 636 & 40 & 1104 & 1851 & 1.2756 & 5.0000 \\
\hline 8 & 1200 & .384 & 746 & 1103 & 1344 & 3243 & .5015 & 4.0000 \\
\hline 9 & 1120 & .251 & 960 & 132 & 1320 & 2653 & 1.0032 & 3.0000 \\
\hline 10 & 1550 & .330 & 1116 & 1829 & 1416 & 2723 & .5272 & 5.0000 \\
\hline 11 & 700 & .411 & 800 & 800 & 1512 & 2475 & .5583 & 6.0000 \\
\hline 12 & 1160 & .496 & 630 & 1185 & 1632 & 2023 & .7889 & 5.0000 \\
\hline 13 & 583 & 1.113 & 331 & 552 & 1872 & 3121 & 1.5000 & 10.0000 \\
\hline 14 & 4505 & 2.553 & 3604 & 4441 & 2136 & 4523 & 2.9557 & 13.0000 \\
\hline 15 & 884 & .669 & 598 & 741 & 1896 & 1821 & 2.6544 & 4.0000 \\
\hline 16 & 1744 & .637 & 1662 & 1997 & 1704 & 2330 & 1.7500 & 4.0000 \\
\hline 17 & 1350 & 1.310 & 1826 & 1588 & 1848 & 2411 & 1.3402 & 8.0000 \\
\hline 18 & 1600 & 1.117 & 1806 & 1290 & 1800 & 3253 & 1.6304 & 12.0000 \\
\hline 19 & 550 & .523 & 523 & 445 & 1464 & 2056 & 1.7846 & 5.0000 \\
\hline 20 & 1060 & .811 & 1060 & 833 & 1512 & 1983 & 2.3779 & 9.0000 \\
\hline
\end{tabular}


Trips Attracted by Zones within Dohuk City by Purpose

\begin{tabular}{|c|c|c|c|c|c|c|}
\hline$\#$ & HBW & HBSH & HBSO & HBOTH & HBED & NHB \\
\hline 1 & 1298 & 343 & 519 & 69 & 770 & 181 \\
\hline 2 & 866 & 14 & 298 & 0 & 1994 & 30 \\
\hline 3 & 2954 & 219 & 270 & 0 & 0 & 137 \\
\hline 4 & 1864 & 74 & 232 & 232 & 2432 & 96 \\
\hline 5 & 293 & 420 & 108 & 46 & 123 & 62 \\
\hline 6 & 955 & 2380 & 109 & 0 & 511 & 58 \\
\hline 7 & 347 & 0 & 165 & 0 & 723 & 0 \\
\hline 8 & 843 & 0 & 60 & 65 & 4018 & 195 \\
\hline 9 & 1640 & 0 & 160 & 0 & 880 & 240 \\
\hline 10 & 1054 & 434 & 124 & 0 & 2232 & 155 \\
\hline 11 & 1100 & 398 & 400 & 0 & 200 & 200 \\
\hline 12 & 908 & 430 & 150 & 250 & 1900 & 175 \\
\hline 13 & 551 & 311 & 537 & 0 & 221 & 79 \\
\hline 14 & 1406 & 256 & 1280 & 384 & 704 & 704 \\
\hline 15 & 713 & 0 & 114 & 0 & 2508 & 57 \\
\hline 16 & 986 & 100 & 350 & 100 & 4350 & 350 \\
\hline 17 & 1985 & 0 & 874 & 0 & 474 & 474 \\
\hline 18 & 2754 & 0 & 416 & 0 & 3060 & 780 \\
\hline 19 & 1367 & 0 & 530 & 0 & 1534 & 130 \\
\hline 20 & 302 & 152 & 608 & 1520 & 100 & 0 \\
\hline
\end{tabular}


Table (3)

Summary of the Model Selected by Stepwise Regression with Constant Results for the Study Area

\begin{tabular}{||l|c|c|}
\hline \multicolumn{1}{|c|}{ Equations } & $\mathrm{R}^{2}$ & $\mathrm{STD}$ \\
\hline $\mathrm{HBW}=691.58+1.461 \mathrm{X}_{2}-95 \mathrm{X}_{1}$ & 0.533 & 532.04 \\
\hline $\mathrm{HBSH}=$ No variables $_{\mathrm{H}}$ & - & - \\
\hline $\mathrm{HBSO}=50.349+449.723 \mathrm{X}_{4}$ & 0.664 & 180.615 \\
\hline $\mathrm{HBOTH}=$ No Variables & - & - \\
\hline $\mathrm{HBED}=$ No Variables & - & - \\
\hline $\mathrm{NHB}=-206.081+122 \mathrm{X}_{2}+199 \mathrm{X}_{6}$ & 0.646 & 136.461 \\
\hline $\begin{array}{l}\text { Total person trip } \\
2437.361+1.057 \mathrm{X}_{2}\end{array}$ & 0.322 & 1281.63 \\
\hline
\end{tabular}

Table (4)

Summary of the Model Selected by Stepwise Regression without Constant Included Results for the Study Area

\begin{tabular}{||l|c|c||}
\hline \multicolumn{1}{|c|}{ Equations } & $\mathrm{R}^{2}$ & $\mathrm{STD}$ \\
\hline $\mathrm{HBW}=180.344 \mathrm{X}_{8}$ & 0.753 & 716.46 \\
\hline $\mathrm{HBSH}=263.186 \mathrm{X}_{7}+0.38 \mathrm{X}_{5}$ & 0.244 & 532.107 \\
\hline $\mathrm{HBSO}=495.124 \mathrm{X}_{4}$ & 0.863 & 178.57 \\
\hline $\mathrm{HBOTH}=131.077 \mathrm{X}_{7}$ & 0.279 & 313.74 \\
\hline $\mathrm{HBED}=1.905 \mathrm{X}_{5}-230.93 \mathrm{X}_{8}$ & 0.779 & $\begin{array}{c}1152.36 \\
1\end{array}$ \\
\hline $\mathrm{NHB}=186 \mathrm{X}_{2}$ & 0.751 & 150.991 \\
\hline Total person trip $=2.389 \mathrm{X}_{5}$ & 0.881 & $\begin{array}{c}1385.24 \\
5\end{array}$ \\
\hline
\end{tabular}


Al-Taei : Trip Attraction Development Statistical Model in Dohuk

Table (5)

Transformations of the HBW Variables on the Independent Variables AEmployment $\left(\mathrm{X}_{2}\right)$, B-No. of $\mathrm{Du}\left(\mathrm{X}_{1}\right)$, and C-No. of Schools $\left(\mathrm{X}_{8}\right)$

\begin{tabular}{|c|c|c|}
\hline \multicolumn{3}{|c|}{ A-No. of Employment $\left(\mathrm{X}_{2}\right)$} \\
\hline Equations & $\mathrm{R}^{2}$ & STD \\
\hline $\mathrm{HBW}=639.6+507 \mathrm{X}_{2}$ & 0.313 & $7.07 X_{10}^{6}$ \\
\hline $\mathrm{HBW}=603.2 \mathrm{e}^{4.52 \times 10-4 \mathrm{X} 2}$ & 0.375 & $9.82 X_{10}^{6}$ \\
\hline $\mathrm{HBW}=21.4 \mathrm{X}_{2}^{0.568}$ & 0.378 & $6.67 \mathrm{X}_{10}^{6}$ \\
\hline $\mathrm{HBW}=1.7 \mathrm{X}_{2}-3.57 \mathrm{X}_{10}^{-4} \mathrm{X}_{2}^{2}$ & 0.517 & $4.98 X_{10}^{6}$ \\
\hline $\mathrm{HBW}=1 /\left(0.00184-5.328 \mathrm{X}_{10}^{-7} \mathrm{X}_{2}\right)$ & 0.486 & - \\
\hline $\mathrm{HBW}=\frac{1324.9 X_{2}}{398.2+X_{2}}$ & 0.232 & $9.5 X_{10}^{6}$ \\
\hline \multicolumn{3}{|c|}{ B-No. of Du $\left(\mathrm{X}_{1}\right)$} \\
\hline Equations & $\mathrm{R}^{2}$ & STD \\
\hline $\mathrm{HBW}=895.6+265 \mathrm{X}_{1}$ & 0.103 & $9.23 X_{10}^{6}$ \\
\hline $\mathrm{HBW}=720.5 \mathrm{e}^{00028 \mathrm{X} 1}$ & 0.224 & - \\
\hline $\mathrm{HBW}=18.9 \mathrm{X}_{1}^{0.577}$ & 0.283 & $9.31 X_{10}^{6}$ \\
\hline $\mathrm{HBW}=40.4+1.45 \mathrm{X}_{1}-2.553 \mathrm{X}_{10}^{-4} \mathrm{X}_{1}^{2}$ & 0.311 & $7.03 X_{10}^{6}$ \\
\hline $\mathrm{HBW}=1 /\left(0.00168-3.8 \mathrm{X}_{10}^{-7} \mathrm{X}_{1}\right)$ & 0.49 & - \\
\hline $\mathrm{HBW}_{1} \frac{248.2 X_{1}}{\overline{\overline{68}} 9.5+X_{1}}$ & 0.278 & $9.5 X_{10}^{6}$ \\
\hline \multicolumn{3}{|c|}{ C-No. of schools $\left(\mathrm{X}_{8}\right)$} \\
\hline Equations & $\mathrm{R}^{2}$ & STD \\
\hline $\mathrm{HBW}=582.2+102.8 \mathrm{X}_{8}$ & 0.176 & $8.48 X_{10}^{6}$ \\
\hline $\mathrm{HBW}=694.5 \mathrm{e}^{0.0627 \mathrm{X} 8}$ & 0.142 & $9.39 X_{10}^{6}$ \\
\hline $\mathrm{HBW}=490 \mathrm{X}_{8}^{0.42}$ & 0.136 & $9.39 \mathrm{X}_{10}^{6}$ \\
\hline $\mathrm{HBW}=415.9+156.7 \mathrm{X} 8-3.548 \mathrm{X}_{8}^{2}$ & 0.178 & $8.46 \mathrm{X}_{10}{ }^{6}$ \\
\hline $\mathrm{HBW}=1 /\left(0.001518-46 \mathrm{X}_{10}{ }^{-5} \mathrm{X}_{8}\right)$ & 0.209 & - \\
\hline HBW $\frac{1243 X_{8}}{\left(\bar{z} .5+X_{8}\right)}$ & 0.208 & $1.23 \mathrm{X}_{10}^{6}$ \\
\hline
\end{tabular}


Table (6)

Summary of the Final Regression Models used for Each Dependent Variable for Study

\begin{tabular}{|l|c|c|}
\hline \multicolumn{1}{|c|}{ Equations } & $\mathrm{R}^{2}$ & $\mathrm{STD}$ \\
\hline $\mathrm{HBW}=180.344 \mathrm{X}_{8}$ & 0.753 & 716.46 \\
\hline $\mathrm{HBSO}=50.349+449.723 \times \mathrm{X}_{4}$ & 0.664 & 180.615 \\
\hline $\mathrm{NHB}=-206.081+0.122 \times \mathrm{X}_{2}+0.199 \times \mathrm{X}_{6}$ & 0.646 & 136.461 \\
\hline $\mathrm{HBSH}=-263.186 \times \mathrm{X}_{7}+0.38 \times \mathrm{X}_{5}$ & 0.244 & 532.107 \\
\hline $\mathrm{HBOTH}=131.077 \times \mathrm{X}_{7}$ & 0.279 & 313.740 \\
\hline $\mathrm{HBED}=1.905 \times \mathrm{X}_{5}-230.93 \times \mathrm{X}_{8}$ & 0.779 & 1152.361 \\
\hline Total person trip $=2.389 \times \mathrm{X}_{5}$ & 0.881 & 1385.245 \\
\hline
\end{tabular}

